\title{
MENUMBUHKAN KESADARAN HUKUM \\ DI MASYARAKAT DAN DUNIA PERGURUAN TINGGI \\ Oleh \\ Warsito
}

\begin{abstract}
Abstrack
Keywords: Legal Awareness, grow in community college.

Compliance community, especially among the students is very important. Legal awareness to their strong adherence to the law, while the weak legal awareness causes of criminality and crime. This study was conducted to describe the condition of legal awareness and legal compliance with laws and the students used different approaches undangan.Penelitian literature through the study of the analysis of textbooks. There is a literature study is all the work done by the researchers to collect information relevant to the topic or issue that will be or are being studied. That information can be obtained from scientific books, research reports, scientific essays, theses and dissertations, regulations, statutes, yearbooks, encyclopedias, and written sources both printed and other electronics. Problems of this study is a society that is still unlawful Some also comply with legal regulations because there are factors that influence. The cause of someone breaking the law is 1) Breaking the law because it does not know the law; 2) breaking the law because they feel powerless or excess material; 3) Unlawful as intentional (dolus). Cause someone obey the law are 1) the compliance that is based on the expectation of a reward and effort to avoid punishment atatu sanctions (compliance), 2) adherence to the rule of law exists not because of its intrinsic value, but that keanggaotaan group is maintained and there is a relationship both by those who are authorized to apply the rules of law (identification), 3) comply with legal rules dikarekan intrinsically earlier compliance has rewards (Internalization).
\end{abstract}

More stringent measures are legal or aggravate threats to tighten the arrangement observance citizens against laws - laws are only incidental and surprise, would not constitute appropriate measures to enhance the legal awareness. Perhaps, for some time it will look or feel their policing but of public awareness can not be enforced and can not be created by the drastic action of an incidental nature only. Efforts to improve the legal awareness through formal and non formal education. Through formal education is instilled notions of law, understand the law, the rights and obligations of citizens of Indonesia, Pancasila and the Constitution of 1945, the Articles in the Code of Penal (Penal Code), how to obtain legal protection. Through non-formal through counseling, campaigns and exhibitions of books, films and others to raise awareness of the law. 


\section{PENDAHULUAN}

\section{A. Latar belakang}

Kesadaran dapat diartikan adanya tekad untuk terlibat secara efektif terhadap suatu tujuan yang mengarah ke arti conscious. Kesadaran disini perlu diberi penegasan, bukan tanpa maksud dan bukan hanya menyangkut masalah kognitif tetapi menyangkut realitas perilaku dalam kehidupan di masyarakat. Menyangkut perilaku secara formal dalam wujud lahiriahnya sebagaimana dituliskan dalam undang-undang, kesadaran perlu ada tindak lanjut yakni penuntasan ke dalam ranah afektif. Dalam aspeknya yang bersifat afektif penanaman nilai-nilai sosial dalam kehidupan keluarga dan masyarakat sangat mempengaruhi proses perkembangannya. Di lingkungan keluarga orang tua telah menetapkan standar perilaku yang bertujuan membawa dampak positif bagi anakanaknya kelak. Standar perilaku tersebut harus dibangun sejak awal dan anak akan melihat realitas di masyarakat mengenai apa yang dipelajarinya, selanjutnya ia akan mulai mempraktikannya di lingkungan kampus yang dampaknya akan sedemikian rupa dan meluas.

Setelah kesadaran hukum dapat dibangun maka akan tumbuh ketaatan terhadap hukum yang berlaku. Ketaatan dan kepatuhan terhadap suatu peraturan yang menjadi undang-undang berdasarkan kekuatan yang bersifat mengatur, mengikat dan memaksa. Kekuatan yang berisifat mengatur akan membuat seseorang terdidik dalam suatu kerangka hukum. Sedangkan kekuatan yang bersifat memaksa akan membuat jera karena ia akan mendapat sanksi yang tegas. Akan timbul pertanyaan apakah kejahatan akan reda jika sudah diterapkan sanksi ? seiring dengan perkembangannya adanya sanksi yang tegas tidak sepenuhnya membuat orang sadar dan taat terhadap hukum. Untuk itu perlu adanya penelaahan secara cermat mengenai kondisi-kondisi objektif yang ada dimasyarakat. Kondisi internal warga masyarakat baik yang berisifat psikologis maupun kultural tidak dapat diabaikan. Subjektifitas dalam bentuk kesedian 
warga untuk menaati hukum tanpa dipaksa, ternyata juga menjadi suatu prasyarat terealisasinya undang-undang secara siginifikan dalam kehidupan sehari-hari.

Tanpa bangkitnya kesediaan warga dalam mengikuti perintah untuk dikerjakan dengan sukarela, tidak setiap usaha untuk mengefektifkan bekerjanya hukum dalam kehidupan bermasyarakat akan dapat terwujud seperti yang diharapkan. Ancaman sanksi sekeras apapun terbukti tidak akan dapat mengontrol perilaku subjek dengan sepenuhnya. Akan selalu saja ada celah dan kesempatan sekecil apapun yang akan coba dimanfaatkan oleh seorang subjek dengan resiko yang telah diperhitungkannya untuk menghindarkan diri dari kontrol hukum yang berhakikat sebagai kontrol eksternal.

Warga masyarakat tidak mudah untuk berpegangan hanya pada suatu komitmen tunggal. Hidup dalam suatu masyarakat yang heterogen karena semakin terspesialisasi peran serta semakin majemuk sebagai akibat perjumpaan beragam budaya. Komitmen untuk menaati hukum nasional seringkali harus bersaing bahkan konflik dengan kepentingan yang arahnya lain. Komitmen itu sangat berkaitan erat dengan kesadaran seseorang untuk membuat pilihan, yang mana yang perlu didahulukan. Terdapat dua aspek mengenai hal ini yakni aspek kognitif (sadar untuk tahu) yakni pengetahuan seseorang tentang ada tidaknya aturan yang mengatur perbuatan yang ia lakukan atau tengah menjadi perhatian utama. Aspek yang kedua adalah afektif yang merujuk keterlibatan dirinya secara emosional ke suatu pihak tertentu, berdasarkan keyakinan bahwa apa yang kita ketahui itu merupakan sesuatu yang benar sehingga sudah seharusnya kalau dituruti dan dipatuhi merupakan sesuatu yang tidak benar dan sudah sepatutnya perlu dilawan.

Kajian-kajian tentang hukum memang bertolak dari suatu anggapan (tidak pernah terbukti) bahwa pengetahuan seseorang akan isi aturan undang-undang berikut ancaman sanksinya sudah cukup bagi warga demi terhindarkan dirinya dari urusan hukum yang selalu mengancam sanksi itu untuk menyerasikan segala tingkah lakunya kepada tuntutan aturan hukum. Semakin heterogen dan 
bertambahnya kemajemukan masyarakat nasional, maka tuntutan untuk menaati hukum tidaknya seseorang pada undang-undang dan isi undang-undang yang telah diundangkan. Seluruh perangkat kampus harus mulai memikirkan dan mempertimbangkan langkah lebih lanjut untuk menjamin ketaatan itu. Dapat dilakukan dengan cara menyelenggarakan penyuluhan untuk menyiarkan, para pejabat yang berkepentingan dalam tertibnya hukum nasional, khususnya di Negara-negara berkembang yang dibangun di atas infrastruktur budaya yang amat majemuk mendahulukan program-program kesadaran hukum lewat strategi yang lebih menyentuh aspek afektif.

Dalam melaksanakan undang-undang yang telah ditetapkan penerapan fungsi mengatur dan memaksa jika menemui jalan buntu, kemauan publik untuk menaatinya itulah yang akan menjadi penentu utama. Dengan demikian sebatas mengerjakan pengabaran dan penyuluhan, kini yang banyak dilakukan ialah sosialisasi dengan strategi yang amat lebih bernuansa edukatif dengan banyak memanfaatkan arah komunikasi timbale balik yang berdasarkan arah asas pendidikan yang terarah. Sebelum program sosialisasi dirancang para pejabat pemerintah untuk mengabarkan berlakunya hukum undang-undang kepada khalayak ramai, sebenarnya warga masyarakat telah tersosialisasi sejak kecil oleh tradisi dan moral yang dikenal dalam pergaulan masyarakat sehari-hari. Sosialisasi yang diupayakan oleh berbagai lembaga yang disponsori oleh Negara baru dimulai jauh setelah itu. Dalam melaksankan fungsi sosialisasi, keluarga dan kerabat selalu berkesempatan mempengaruhi para warganya, lama sebelum para warga masyarakat ini mengalami proses resosialisasi dan mengenali identitasnya sebagai warga suatu Negara.

\section{B. Permasalahan}

Permasalahan yang muncul adalah adanya masyarakat kampus yang tetap melanggar peraturan yang ada serta ada yang mematuhi peraturan karena ada factor-faktor yang mempengaruhi. Adapun faktor-faktor yang mempengaruhi kesadaran hukum adalah : 
1. Pengetahuan tentang kesadaran hukum Secara umum, perturan-peraturan yang telah sah, maka dengan sendirinya peraturan-peraturan tadi akan tersebar luas dan diketahui umum. Tetapi sering kali terjadi suatu golongan tertentu di dalam mayarakat tidak mengetahui atau kurang mengetahui tentang ketentuanketentuan hukum yang khusus bagi mereka.

2. Pengakuan terhadap ketentuan-ketentuan hukum, Pengakuan masyarakat terhadap ketentuan-ketentuan hukum, berati bahwa masyarakat mengetahui isi dan kegunaan dari norma-norma hukum tertentu arrtinya ada suatu derajat pemahaman yang tertentu terhadap ketentuan-ketentuan hukum yang berlaku. Namun hal ini belum merupakan jaminan bahwa warga masyarakat yang mengakui ketentuan-ketentuan hukum tertentu dengan sendirinya mematuhinya, tetapi juga perlu diakui bahwa orang-orang yang memahami suatu ketentuan hukum adakalanya cenderung untuk mematuhinya.

3. Penghargaan terhadap ketentuan-ketentuan hukum, Penghargaan atau sikap tehadap ketentuan-ketentuan hukum, yaitu sampai sejauh manakah suatu tindakan atau perbuatan yang dilarang hukum diterima oleh sebagian besar warga masyarakat. Juga reaksi masyarakat yang didasarkan pada sistem nilainilai yang berlaku. Masyarakat mungkin menentang atau mungkin mematuhi hukum, karena kepentingan mereka terjamin pemenuhannya.

4. Pentaatan atau kepatuhan terhadap ketentuan-ketentuan hukum, Salah satu tugas hukum yang penting adalah mengatur kepentingan-kepentingan para warga masyarakat. Kepentingan para warga masyarakat tersebut lazimnya bersumber pada nilai-nilai yang berlaku, yaitu anggapan tentang apa yang baik dan apa yang harus dihindari.

5. Ketaatan masyarakat terhadap hukum, dengan demikian sedikit banyak tergantung apakah kepentingan-kepentingan warga masyarakat dalam bidangbidang tertentu dapat ditampung oleh ketentuan-ketentuan hukum. Ada juga suatu anggapan bahwa kepatuhan hukum disebabkan karena adanya rasa takut pada sanksi, karena ingin memelihara hubungan baik dengan rekan-rekan sekelompok atau pimpinan karena kepentingannya terlindung, karena cocok dengan nilai-nilai yang dianutnya. 


\section{Pembahasan}

\section{Indikator Kesadaran Hukum}

Terdapat empat indikator kesadaran hukum, yang masing-masing merupakan suatu tahapan berikutnya, yaitu 1) Pengetahuan hukum, 2) Pemahaman hukum, 3) Sikap hukum, 4) Pola prilaku hukum (soerjono soekanto, 1982: 140)

Setiap indikator menunjuk pada tingkat kesadaran hukum tertentu mulai dari yang terendah sampai dengan yang tertinggi.

a. Pengetahuan hukum adalah pengetahuan seseorang mengenai beberapa perilaku tertentu yang diatur oleh hukum. Pengetahuan tersebut berkaitan dengan prilaku yang dilarang ataupun prilaku yang diperbolehkan oleh hukum. Seperti yang terlihat di dalam masyarakat bahwa pada umumnya seseorang mengetahui bahwa membunuh, mencuri, dan seterusnya dilarang oleh hukum. Pengetahuan hukum tersebut erat kaitannya dengan asumsi bahwa masyarakat dianggap mengetahui isi suatu peraturan manakala peraturan tersebut telah diundangkan.

b. Pemahaman hukum mengenai isi peraturan dari hukum tertentu. Dengan lain perkataan pemahaman hukum adalah suatu pengertian terhadap isi dan tujuan dari suatu peratuan dalam suatu hukum tertentu, tertulis maupun tidak tertulis, serta manfaatnya bagi pihak-pihak yang kehidupannya tidak disyaratkan seseorang harus terlebih dahulu mengetahui adanya suatu aturan tertulis

c. Sikap hukum adalah suatu kecenderungan untuk menerima hukum karena adanya penghargaan terhadap hukum sebagai sesuatu yang bermanfaat atau menguntungkan jika hukum itu ditaati.

d. Perilaku hukum, Pola perilaku hukum merupakan hal utama dalam kesadaran hukum karena disini dapat dilihat apakah suatu peraturan berlaku atau tidak dalam masyarakat.

Terdapat kaitan atara kesadaran hukum dengan kebudayaan hukum. keterkaitan tersebut dapat dilihat bahwa kesadaran hukum banyak sekali berkaitan dengan aspek-aspek kognitif dan perasaan yang seringkali dianggap faktor-faktor 
yang mempengaruhi hubungan antara hukum dengan pola-pola perilaku manusia dalam masyarakat. Ajaran kesadaran hukumn lebih banya mempermasalahkan kesadaran hukum yang dianggap sebagai mediator antar hukum dengan perilaku manusia baik secara individual maupun kolektif. Oleh karennya ajaran kesadaran hukum lebih menitik beratkan kepada nilai-nilai yang berlaku pada masyarakat. Sistem nilai-nilai akan menghasilkan patokan-patokan untuk berproses yang bersifat psikologis, antara lain pola-pola berfikir yang menentukan sikap mental manusia, sikap mental yang pada hakikatnya merupakan kecenderungan untuk bertingkah laku , membentuk pola-pola perilaku maupun kaidah-kaidah.

Keempat indikator tadi sekaligus menunjukkan pada tingkat-tingkatan kesadaran hukum tertentu di dalam perwujudannya. Apabila seseorang hanya mengetahui hukum, maka dapat dikatakan bahwa tingkat kesadaran hukumnya masih rendah, tetapi kalau seseorang dalam suatu masyarakat telah berperilaku sesuai dengan hukum, maka kesadaran hukumnya tinggi.

\section{Penyebab Masyarakat Melanggar Hukum}

Setiap manusia mempunyai kebutuhan yang berbeda-beda satu dengan yang lainnya. Untuk memenuhi kebutuhan hidupnya tersebut manusia akan melakukan segala cara. Sering terjadi hal tesebut adalah hal melanggar hukum.

\section{a. Melanggar hukum karena memang tidak tahu hukum;}

Sebenarnya tidak ada manusia yang tidak tahu hukum, karena hukum itu sendiri ada di tengah-tengah masyarakat, dimana ada masyarakat, disitulah ada hukum. Hanya saja, di Indonesia banyak sekali undang-undang yang telah dibuat pemerintah dan sangat disayangkan bahwa tidak semua Undang-Undang tersebut menyentuh seluruh lapisan masyarakat. Mulai dari alasan sosialisasi yang kurang, malas tahu, dan sebagainya. Conton saja, undang-undang tentang Pornografi, 
banyak masyarakat yang tidak tau isi dari undang -undang tersebut dan sanksi apa yang dikenakan bagi para pelanggarnya.

\section{b. Manusia melanggar hukum karena merasa punya kekuasaan atau materi berlebih;}

Banyak orang yang mempunyai kekuasaan atau jabatan yang tinggi merasa hal itu adalah segala-galanya sehingga tidak mempedulikan peraturan yang berlaku. Padahal dalam Undang-Undang dijelaskan bahwa setiap orang mempunyai kedudukan yang sama dihadapan hukum. Tetapi pada kenyataannya banyak pejabat atau artis yang mempunyai popularitas dan materi yang banyak sehingga jika tersangkut sebuah kasus maka terlihat sangat mudah kasus itu cepat selesai penanganannya atau jika pun ada sanksi maka sanksi yang dijatuhkan sangatlah ringan.

\section{c. Melanggar hukum karena kesengajaan (Dolus)}

Dolus adalah kehendak yang disadari yang ditujukan untuk melakukan pelanggaran atau kejahatan tertentu contohnya yaitu Pasal 338 KUHP tentang tindak pidana pembunuhan, Pasal 245 KUHP tentang tindak pidana pemalsuan mata uang. Masyarakat umumnya tahu tentang tindak pidana pembunuhan merupakan pelanggaran hukum, namun tidak sedikit masyarakat yang tetap melakukannya hanya untuk kepuasan emosional tanpa memikirkan dampaknya. Baik itu untuk dirinya sendiri maupun untuk orang lain. Sama halnya dengan tindak pidana pemalsuan mata uang.

\section{Penyebab Masyarakat mematuhi Hukum}

Adapun faktor-faktor yang dapat menyebabkan masyarakat mematuhi kesadaran hukum antara lain sebagai berikut :

a. Compliance, sebagaimana disebut diatas, diartikan sebagai suatu kepatuhan yang didasarkan pada harapan akan suatu imbalan dan usaha untuk menghindarkan diri dari hukuman atatu sanksi yang mungkin dikenakan 
apabila seseorang melanggar ketentuan hukum.kepatuhan ini sama sekali tidak didasarkan pada suatu keyakinan pada tujuan kaidah hukum yang bersangkutan, dan lebih didasarkan pada pengendalian dari pemegang kekuasaan. Sebagai akibatnya, kepatuhan hukum akan ada apabila ada pengawasan yang ketat terhadap pelaksanaan kaidah-kaidah hukum tersebut.

b. Identification, terjadi bila kepatuhan terhadap kaidah hukum ada bukan karena nilai intrinsiknya, akan tetapi agar keanggaotaan kelompok tetap terjaga serta ada hubungan baik dengan mereka yang diberi wewenang untuk menerapkan kaidah-kaidah hukum tersebut. Daya tarik untuk patuh adalah keuntungan yang diperoleh dari hubungan-hubungan tersebut sehingga kepatuhanpun tergantung pada buruk baiknya interaksi tadi.

c. Internalization, pada tahap ini seseorang mematuhi kaidah-kaidah hukum dikarekan secara intrinsik kepatuhan tadi mempunyai imbalan. Isi kaidahkaidah tersebut adalah sesuai dengan nilai-nilainya dari pribadi yang bersangkutan, atau oleh AZkarena dia mengubah nilai-nilai yang semula dianutnya. Hasil dari proses tersebut adalah suatu komformitas yang didasarkan pada motivasi secara intrinsik. Titik sentral dari kekuatan proses ini adalah kepercayaan orang tadi terhadap tujuan dari kaidah-kaidah bersangkitan, terlepas dari pengaruh atau nilai-nilainya terhadap kelompok atau pemegang kekuasaan maupun pengawasanya.

\section{Upaya Meningkatkan Kesadaran Hukum}

Meningkatnya jumlah kecelakaan lalu lintas sering terjadi di lingkungan masyarakat. Jumlah kendaraan bermotor meningkat, tetapi apabila para pemakai jalan raya terutama para pengendara kendaraan bermotor mentaati peraturan lalu lintas dan para petugas ketat mengawasinya serta sikapnya tegas dan konsekuen menghadapi pelanggaran -pelanggaran lalu lintas, kecelakaan lalu lintas tidak perlu terjadi seperti sekarang ini. Mengabaikan rambu-rambu lalu lintas terjadi 
setiap hari. Kendaraan umum dan terutama kendaraan bermotor beroda dua sering membuat kesal dan gelisah pemakai jalan lainnya. Kecuali dengan suara knalpot yang mempekakan telinga juga dengan cara mengendarai kendaraannya sehingga membahayakan lalu lintas. Pendek kata kesopanan lalu lintas diabaikan. Bukan hanya itu saja, tangggung jawab para pengendara kendaraan bermotor dapat dikatakan pada umumnya menurun.

Untuk dapat mengambil langkah-langkah guna mengatasi menurunnya kesadaran hukum masyarakat, perlu kiranya diketahui apakah kiranya yang dapat menjadi sebab- sebabnya. Menurunnya kesadaran hukum masyarakat itu merupakan gejala perubahan di dalam masyarakat yaitu perubahan sosial. Salah satu sebab perubahan sosial menurut Arnold M Rose (dalam Soerjono Soekanto, 1975: 35) adalah kontak atau konflik antar kebudayaan. Besarnya arus pariwisatawan yang mengalir ke Indonesia tidak sedikit pengaruhnya dalam merangsang perubahan-perubahan sosial. Pengaruh film terutama film luar negeri serta televisi, majalah atau bacaan-bacaan lainnya dengan adegan - adegan atau cerita yang sadis tidak berperikemanusiaan atau asusila mempunyai peran penting dalam membantu menurunkan kesadaran hukum masyarakat.

Kurang tegas dan konsekuensinya para petugas penegak hukum terutama polisi, jaksa dan hakim dalam menghadapi pelanggaran-pelanggaran hukum pada umumnya merupakan peluang terjadinya pelanggaran-pelanggaran atau kejahatankejahatan. Tidak adanya atau kurangnya pengawasan pada petugas penegak hukum merupakan perangsang menurunnya kesadaran hukum masyarakat. Adanya golongan, pejabat-pejabat dan pemimpin-pemimpin tertentu yang seakanakan kebal terhadap hukum karena mereka berbuat dan dapat berbuat semaunya.

Tindakan drastis dengan misalnya memperberat ancaman hukum atau dengan lebih mengetatkan penataan ketaatan warga negara terhadap undang-undang saja yang hanya bersifat insidentil dan kejutan, kiranya bukanlah merupakan tindakan yang tepat untuk meningkatkan kesadaran hukum masyarakat. Mungkin untuk beberapa waktu lamanya akan tampak atau terasa adanya penertiban tetapi 
kesadaran hukum masyarakat tidak dapat dipaksakan dan tidak mungkin diciptakan dengan tindakan yang drastis yang bersifat insidentil saja. Kita harus menyadari bahwa setelah mengetahui kesadaran hukum masyarakat dewasa ini, yang menjadi tujuan kita pada hakekatnya bukanlah semata-mata sekedar meningkatkan kesadaran hukum masyarakat saja, tetapi membina kesadaran hukum masyarakat. Seperti yang telah diketengahkan di muka maka kesadaran hukum erat hubungannya dengan hukum, sedang hukum adalah produk kebudayaan. Usaha peningkatan dan pembinaan yang utama, efektif dan efisien ialah dengan pendidikan. Pendidikan tidaklah merupakan suatu tindakan yang "einmalig" atau insidentil sifatnya, tetapi merupakan suatu kegiatan yang kontinyu dan intensif dan terutama dalam hal pendidikan kesadaran hukum ini akan memakan waktu yang lama.

Peningkatan kesadaran hukum masyarakat pada dasarnya dapat dilakukan melalui dua cara, yaitu dalam bentuk tindakan (action) dan pendidikan (education). Berikut penjelasannya :

\section{a. Tindakan (action)}

Tindakan penyadaran hukum pada masyarakat dapat dilakukan berupa tindakan drastis, yaitu dengan memperberat ancaman hukuman atau dengan lebih mangetatkan pengawasan ketaatan warga negara terhadap undang-undang. Cara ini bersifat insidentil dan kejutan dan bukan merupakan tindakan yang tepat untuk meningkatkan kesadaran hukum masyarakat

\section{b. Pendidikan (education)}

Pendidikan dapat dilakukan baik secara formal maupun nonformal. Hal yang perlu diperhatikan dan ditanamkan dalam pendidikan formal/nonformal adalah pada pokoknya tentang bagaimana menjadi warganegara yang baik, tentang apa hak serta kewajiban seorang warga negara.

Menanamkan kesadaran hukum berarti menanamkan nilai-nilai kebudayaan. Dan nilai-nilai kebudayaan dapat dicapai dengan pendidikan. Oleh karena itu 
setelah mengetahui kemungkinan sebab-sebab merosotnya kesadaran hukum masyarakat usaha pembinaan yang efektif dan efesien ialah dengan pendidikan.

\section{Pendidikan formal}

Pendidikan sekolah merupakan hal yang lumrah dalam kehidupan berbangsa dan bernegara. Pendidikan kesadaran hukum di sekolah harus dilakukan dari tingkat rendah/ sampai jenjang pendidikan tinggi. Perlu penanaman mengenai hak dan kewajiban warga negara Indonesia, Pancasila dan Undang-undang Dasar, Pasal-pasal dalam Kitab Undang-Undang Hukum Pidana (KUHP), bagaimana cara memperoleh perlindungan hukum.

\section{Pendidikan Non Formal}

Pendidikan non formal ditujukan kepada masyarakat luas meliputi segala lapisan dalam masyarakat. Pendidikan non formal dapat dilakukan dengan beberapa cara, antara lain: penyuluhan hukum, kampanye,dan pameran.

\section{a. Penyuluhan Hukum}

Penyuluhan hukum adakah kegiatan untuk meningkatkan kesadaran hukum masyarakat berupa penyampaian dan penjelasan peraturan hukum kepada masyarakat dalam suasana informal agar setiap masyarakat mengetahui dan memahami apa yang menjadi hak, kewajiban dan wewenangnya, sehingga tercipta sikap dan prilaku berdasarkan hukum, yakni disamping mengetahui, memahami, menghayati sekaligus mematuhi /mentaatinya.

Penyuluhan hukum dapat dilakukan melalui dua cara : pertama, penyuluhan hukum langsung yaitu kegiatan penyuluhan hukum berhadapan dengan masyarakat yang disuluh, dapat berdialog dan bersambung rasa misalnya : ceramah, diskusi, temu, simulasi dan sebagainya. Kedua, penyuluhan hukum tidak langsung yaitu kegiatan penyuluhan hukum yang dilakukan tidak berhadapan dengan masyarakat yang disuluh, melainkan melalui media/perantara,seperti radio, televisi, video, majalah, surat kabar, film, dan lain sebagainya.

Penyuluhan hukum yang tidak langsung dalam bentuk bahan bacaan, terutama ceritera bergambar atau strip yang bersifat heroik akan sangat membantu dalam 
meningkatkan kesadaran hukum masyarakat. Buku pegangan yang berisi tentang hak dan kewajiban warga negara Indonesia, susunan negara kita, Pancasila dan Undang-undang Dasar, pasa-pasal yang penting dalam KUHP, bagaimana caranya memperoleh perlindungan hukum perlu diterbitkan.

Penyuluhan hukum bertujuan untuk mencapai kesadaran hukum yang tinggi dalam masyarakat, sehingga setiap anggota masyarakat menyadari hak dan kewajibannya sebagai warga Negara, dalam rangka tegaknya hukum, keadilan, perlindungan terhadap harkat dan martabat manusia, ketertiban, ketentraman, dan terbentuknya perilaku warga negara yang taat pada hukum.

\section{b Kampanye}

Kampanye peningkatan kesadaran hukum masyarakat dilakukan secara terus menerus yang diisi dengan kegiatan-kegiatan yang disusun dan direncanakan,seperti : ceramah, berbagai macam perlombaan, pemilihan warga negara teladan dan lain sebagainya.

\section{c Pameran}

Suatu pameran mempunyai fungsi yang informatif edukatif. Maka tidak dapat disangkal peranannya yang positif dalam meningkatkan dan membina kesadaran hukum masyarakat. Dalam pameran hendaknya disediakan buku vademecum, brochure serta leaflets di samping diperlihatkan film, slide,VCD dan sebagainya yang merupakan visualisasi kesadaran hukum yang akan memiliki daya tarik masyarakat yang besar.

Dan pada akhirnya dalam upaya mensukseskan peningkatan kesadaran hukum masyarakat masih diperlukan partisipasi dari para pejabat dan pemimpinpemimpin.

\section{Penutup}

\section{Kesimpulan}


Kesdaran hukum merupakan cara pandang masyarakat terhadap hukum itu, apa yang seharusnya dilakukan dan tidak dilakukan. Pada hakikatnya kesadaran hukum bukanlah kesadaran akan hukum, tetapi terutama adalah kesadaran akan adanya atau terjadinya "tidak hukum" atau "onrecht". Terdapat empat indikator kesadaran hukum, yang masing-masing merupakan suatu tahapan berikutnya, yaitu : Pengetahuan hukum, Pemahaman hukum, Sikap hukum, Pola prilaku hukum. Kondisi suatu masyarakat terhadap kesadaran hukum dapat kita kemukakan dalam beberapa parameter, antara lain: ditinjau dari segi bentuk pelanggaran, segi pelaksanaan hukum, segi jurnalistik, dan dari segi hukum. Terdapat faktor yang menyebabkan masyarakat mematuhi hukum yaitu compliance, identification, internalization. Peranan hukum dalam pembangunan dimaksudkan agar pembangunan tersebut berlangsung secara tertib dan teratur, sehingga tujuan pembangunan tersebut dapat dicapai sesuai dengan yang telah ditetapkan. Adapun cara untuk meningkatkan kesadarran hukum yaitu dapat berupa tindakan, dan pendidikan. Tindakan berarti dengan memperberat ancaman hukuman atau dengan lebih mangetatkan pengawasan ketaatan warga negara terhadap undang-undang sehingga diupayakan semua masyarakat patuh. Kemudian pendidikan berarti berarti mengajarkan bahwa setiap manusia diupayakan memiliki kesadaran hukum tentang bagaimana menjadi warga negara yang baik, baik di laksanakan dipendidikan formal ataupun nonformal.

\section{Saran}

a. Sebagai pelaksana undang-undang perlu melakukan sosialisasi produk hukum kepada masyarakat.

b. Bentuk sosialisasi dari desa sampai kota agar masyarakat mengerti tentang hukum.

c. Lembaga perguruan tinggi diharapkan bisa membantu dalam melakukan pendidikan kepada masyarakat

\section{E. Daftar Pustaka}


Arif Fakrulah, Sudan. 2009. Memahami Hukum dari Konstruksi sampai Implementasi. Jakarta. Rajawali Pers.

Kansil. 1989. Pengantar Ilmu Hukum dan Tata Hukum Indonesia. Jakarta. Balai Pustaka.

Soerjono Sukanto, 1982. Beberapa permasalahan hukum dalam kerangka pembangunan di Indonesia, Yayasan Penerbit UI.

Soeroso, Pengantar Ilmu Hukum, Jakarta. Sinar Grafika

http://www.kesadaran hukum dalam masyarakat.com 